\title{
PHYSICAL MODELING OF PLASTIC WORKING CONDITIONS FOR RODS OF 7xxx SERIES ALUMINUM ALLOYS
}

\begin{abstract}
The continuing high level of demand for lightweight structural materials is the reason for the ever-growing interest in aluminum alloys. The main areas of application for aluminum alloys products are the aerospace and automotive industries. Production of profiles and structural elements from lightweight alloys gives possibility to reduce the curb weight of construction, which directly translates into among other reduction of fuel consumption and lower amount of generated exhaust gas.

Determination of heat treatment and plastic working parameters to obtain the required mechanical properties of the manufactured products is a complex process that requires among others knowledge of the material behavior during the deformation process. To carry out the study the torsion plastometer STD 812 was used. On the basis of obtained results of the research the value of the yield stress, formability limit and the thermal effect of the deformed 7xxx series aluminum alloy were specified for different schemes and conditions of deformation.
\end{abstract}

Keywords: aluminun alloys, the state of deformation, torsion test, tensile test, complex deformation state

\section{Introduction}

$7 \mathrm{xxx}$ series aluminum alloys because of its high strength properties are used in many industries. Increasingly being used for the production of load-bearing bridges, trucks, trailers, semi-trailers buses, ships, cranes and railway wagons. They are applied also as elements of aerospace structures, tanks, mining equipments, hydraulic systems and in the shipbuilding industry. Additionally the advantage of the 7xxx series aluminum alloys is a very good thermal conductivity, relatively good corrosion resistance and high machinability [1-4].

Significant influence on the properties of the resulting finished product has a way of plastic working. In case of plastic forming processes the fundamental feature characterising the materials susceptibility for plastic forming is a yield stress $\sigma_{p}$, which under uniaxial sress state is a function of strain $(\varepsilon)$, strain rate $(\dot{\varepsilon})$, temperature $(T)$ and strain history course [5-8]. There are many research methods used to determine the value of yield stress, which include: tensile, compression and torsion tests $[5,9]$. They can be used indirectly to determine the process parameters of plastic working. Usage a torsion test at elevated temperatures allows to determine yield stress in an indirect manner, using the hypothesis of material effort. The main advantages of this method are: lack of friction, time-invariable state of stress and the possibility of achieving a much greater strain than in the other two methods $[5,9,10]$. Method of hot torsion allows for such matching of the process conditions in which it is possible to achieve a constant strain rate and modeling of complex deformation scheme [11]. Generating in material the deformation scheme with high value of total strain significantly improves the mechanical properties of the finished product. Examples of processes in which the material undergoes large plastic deformations are methods SPD (Severe Plastic Deformation), such as: High Pressure Torsion (HPT), Equal Channel Angular Pressing (ECAP) or cyclic rolling of the composite material (ARB - Accumulative Roll Bonding). To the methods of plastic working undoubtedly characterized by a complex deformation scheme, the process of rods or tubes rolling in the three high skew rolling mill can be included [6,12-14]

When carrying out the design for the plastic working process of material in complex deformation state, it is reasonable to conduct basic research on torsion plastometer to determine the yield stress of investigated material.

\section{Material and experimental procedure}

Material used for the study was the 7xxx series aluminum alloy. The chemical composition of the alloy has been shown in Table 1.

\footnotetext{
CZESTOCHOWA UNIVERSITY OF TECHNOLOGY, FACULTY OF PRODUCTION ENGINEERING AND MATERIALS TECHNOLOGY, INSTITUTE OF METAL FORMING AND SAFETY ENGINEERING, CZESTOCHOWA, 19 ARMII KRAJOWEJ AV., 42-200 CZESTOCHOWA, POLAND

** KAZAKH NATIONAL RESEARCH TECHNICAL UNIVERSITY AFTER K.I. SATPAYEV, ALMATY, REPUBLIC OF KAZAKHSTAN

\# Corresponding author: tbajor@wip.pcz.pl
} 
TABLE 1 using torsion plastometer were prepared as shown in Fig. 1. For

Chemical composition of 7075 aluminum alloy [\%]

\begin{tabular}{|c|c|c|c|c|c|c|c|c|c|c|}
\hline Al & Zn & Mg & $\mathrm{Cu}$ & $\mathrm{Fe}$ & Si & Mn & $\mathrm{Cr}$ & $\mathrm{Zr}$ & $\mathrm{Ti}$ & Others \\
\hline Rest & $5.1-6.1$ & $2.1-2.9$ & $1.2-2.0$ & $\begin{array}{l}\max \\
0.50\end{array}$ & $\begin{array}{l}\max \\
0.40\end{array}$ & $\begin{array}{l}\max \\
0.30\end{array}$ & $0.18-0.28$ & $\begin{array}{l}\max \\
0.25\end{array}$ & $\begin{array}{l}\max \\
0.20\end{array}$ & $\begin{array}{l}\max \\
0.05\end{array}$ \\
\hline
\end{tabular}

The proposed research methodology involved a tensile test, torsion and tensile simultaneously with torsion. The examinations were carried out using STD 812 torsion plastometer.

The examinations on torsion plastometer were carried out at temperatures of $200^{\circ} \mathrm{C}, 300^{\circ} \mathrm{C}$ and $400^{\circ} \mathrm{C}$ for strain rate equal $1 \mathrm{~s}^{-1}$. For each temperature-speed variant tensile tests, torsion and tensile with torsion were conducted. Tests were performed in a vacuum at a constant temperature of deformed sample and at a constant deformation rate. To plastometric tests were used round samples with diameter of $d=6 \mathrm{~mm}$ and length of the measurement base $l=10 \mathrm{~mm}$. Specimens for tests carried out registration and control of temperature changes thermocouple type $\mathrm{K}(\mathrm{NiCr}-\mathrm{Ni})$ welded onto the sample surface was used. Samples were inductively heated at a constant rate of $5^{\circ} \mathrm{C} / \mathrm{s}$ to a given temperature, holded at this temperature for $10 \mathrm{~s}$, and then deformed. An analysis of the material structure was done. The identification of the structure constituents in the 7075 aluminum alloy was done on JSM 5400 scanning microscope furnished with an EDS OXFORD INSTRUMENTS ISIS 300 X-ray microanalyzer using EBSD technique.

An important element of the study was the use of infrared camera ThermaCAM SC640 by FLIR Systems (Fig. 2), in order to determine the actual temperature of the material during the deformation process. Main parameters used for the studies using the infrared technique were shown in Table 2. While in Figure 3 was shown an example TechnoGR from infrared camera which was the basis for temperature determination of the sample during the deformation process.

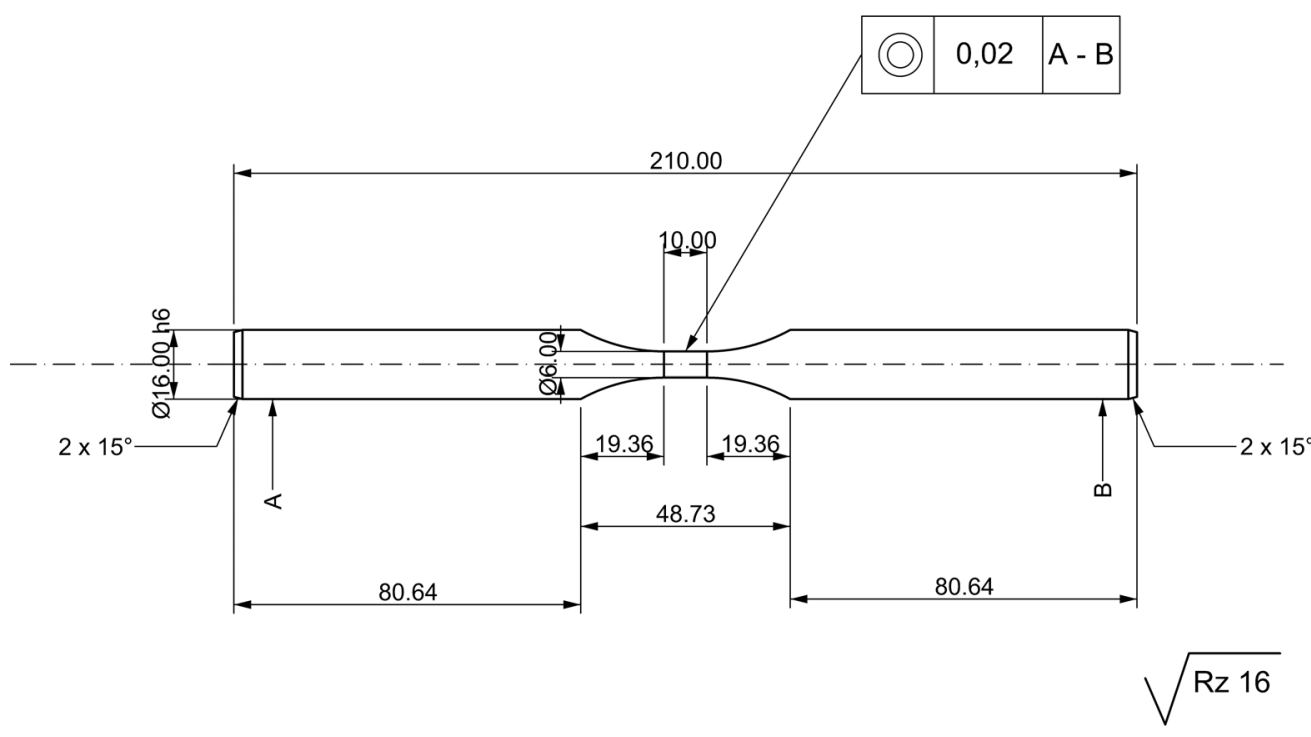

Fig. 1. Dimensions of the sample prepared for testing on STD torsion plastometer

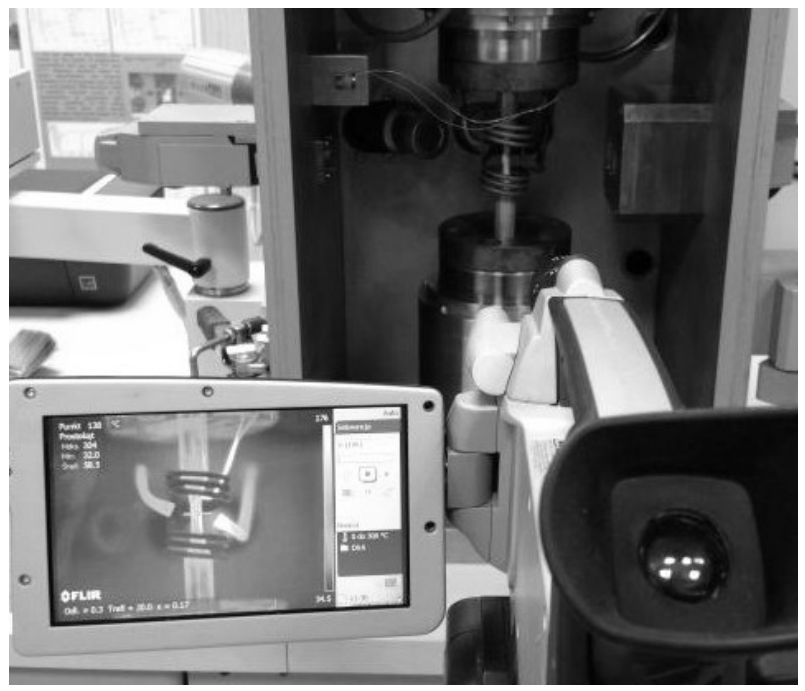

Table 2. Parameters of the object

\begin{tabular}{|c|c|}
\hline Parameter & Value \\
\hline Emissivity & $\mathbf{0 . 0 8} \div \mathbf{0 . 2 5}$ \\
\hline Distance & $0.25 \mathrm{~m}$ \\
\hline Reflected Temperature & $20.0^{\circ} \mathrm{C}$ \\
\hline Air temperature & $20.0^{\circ} \mathrm{C}$ \\
\hline Relative humidity & $50 \%$ \\
\hline
\end{tabular}

Fig. 2. Temperature measurement of the sample using thermovision technology 


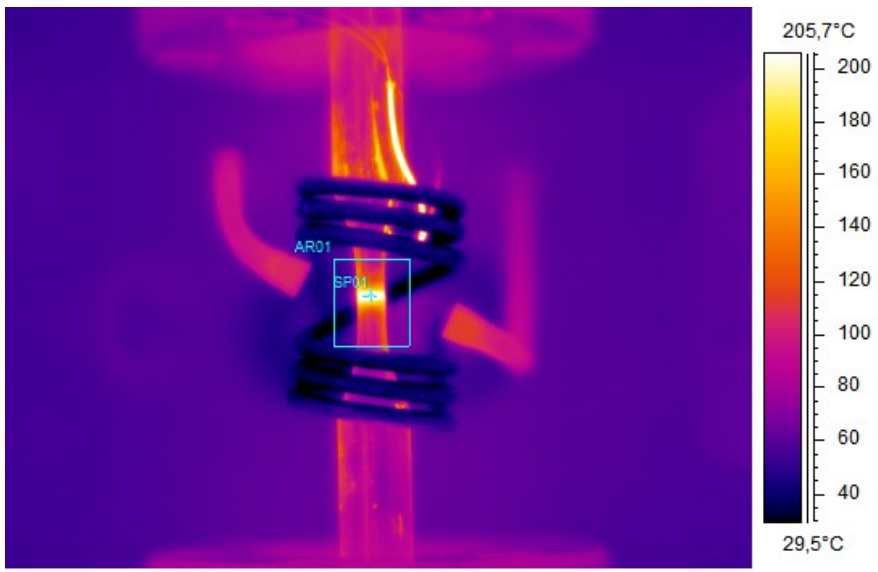

Fig. 3. Example of thermogram from the infrared camera during the process of deformation $7 \mathrm{xxx}$ series aluminum alloy

\section{Experimental results}

Data obtained from the research were analysed. In Fig. 3-5 were shown the flow curves of investigated aluminum alloy during deformation at different temperatures with the changes of sample temperature registered by infrared camera.

Based on the analysis of the data shown in Fig. 4, it was found that during the tensile of $7 \mathrm{xxx}$ series aluminum alloy the highest values of yield stress occurred at temperature of $200^{\circ} \mathrm{C}$ while the lowest values during the tensile of the sample

a)

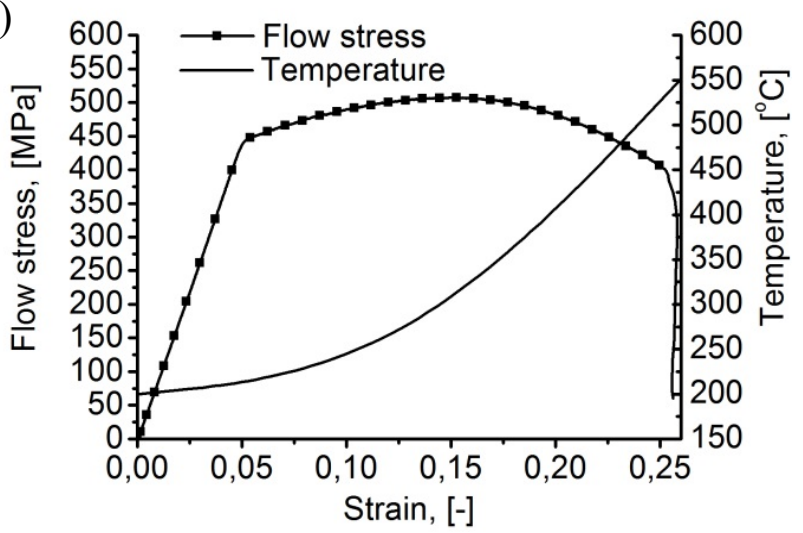

c)

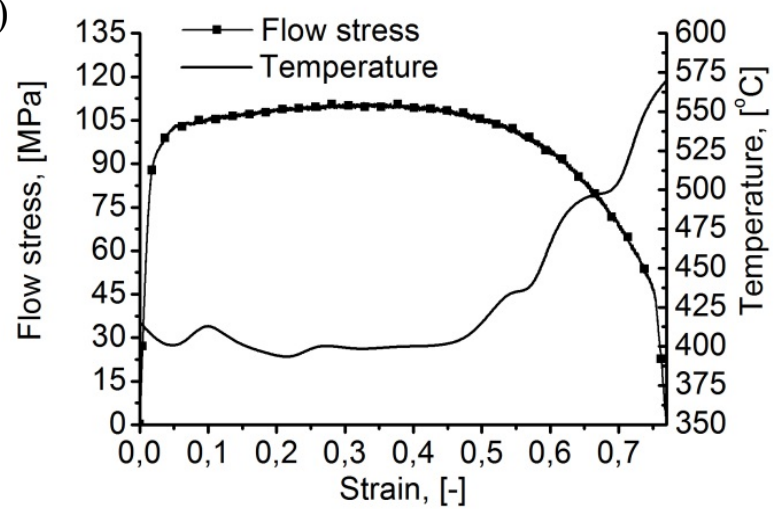

at temperature of $400^{\circ} \mathrm{C}$. The deformation of the material at temperature of $200^{\circ} \mathrm{C}$ resulted in the largest thermal effect of the process. The maximum temperature recorded in the working portion of the sample was $550^{\circ} \mathrm{C}$, which means that increased by about $350^{\circ} \mathrm{C}$ in relation to the initial temperature of the process. The material tested in these conditions was characterized also by the smallest plasticity. The limiting strain (limiting value of deformation) of investigated alloy was 0.25 . From these curves it can be seen that the yield stress of the sample increased its value, despite the simultaneous increase in temperature of the material until it reaches a maximum value at true strain of about 0.15 . In the course of further deformation can be observed only a slight decrease in the yield stress.

Analyzing the changes of yield stress for the sample tensioned at temperature $300^{\circ} \mathrm{C}$ (Fig. 4b) it was stated a significant influence of temperature on the reduction in the level of yield stress as compared to the values of yield stress during the tensile test at temperature of $200^{\circ} \mathrm{C}$. The stress was decreased to about $300 \mathrm{MPa}$. This helped to improve the plasticity of the tested alloy and to reduce the thermal effect of the process. The limiting strain was approx. 0.37, whereas registered temperature growth in the central portion of the sample was approx. $175^{\circ} \mathrm{C}$.

The growth of testing temperature to the level of $400^{\circ} \mathrm{C}$ (Fig. 4c) caused increase of the material plasticity. The limiting strain rise to approx. 0.75 . The thermal effect was about $150^{\circ} \mathrm{C}$. The highest value of yield stress was reached at true strain equaled about 0.3 .

b)

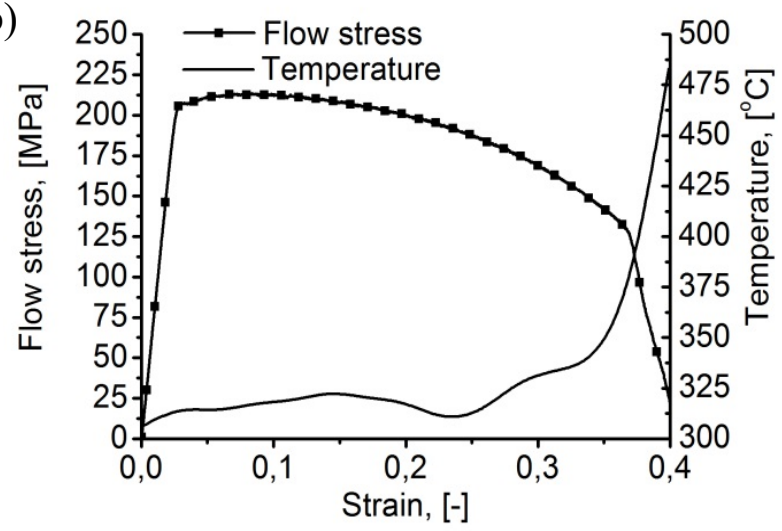

Fig. 4. Stress-strain dependencies received during tensile test with deformation rate $1 \mathrm{~s}^{-1}$ at temperature of: a) $\left.200^{\circ} \mathrm{C} \mathrm{b}\right) 300^{\circ} \mathrm{C}$ c) $400^{\circ} \mathrm{C}$ 
Different than during tensile the course of yield stress of investigated 7075 aluminum alloy was observed during of a constrained torsion test (Fig. 5). Analysing the limiting strain of tested under these conditions alloy has been found beneficial effect of change the deformation scheme to the limiting strain of the material, which was respectively: 1.7 (at temperature of $200^{\circ} \mathrm{C}$ ), 4.75 (at temperature of $300^{\circ} \mathrm{C}$ ) and 6.3 (at temperature of $400^{\circ} \mathrm{C}$ ). Analyzing the results received from torsion test was also found the thermal effect lower than in case of tensile test.

a)

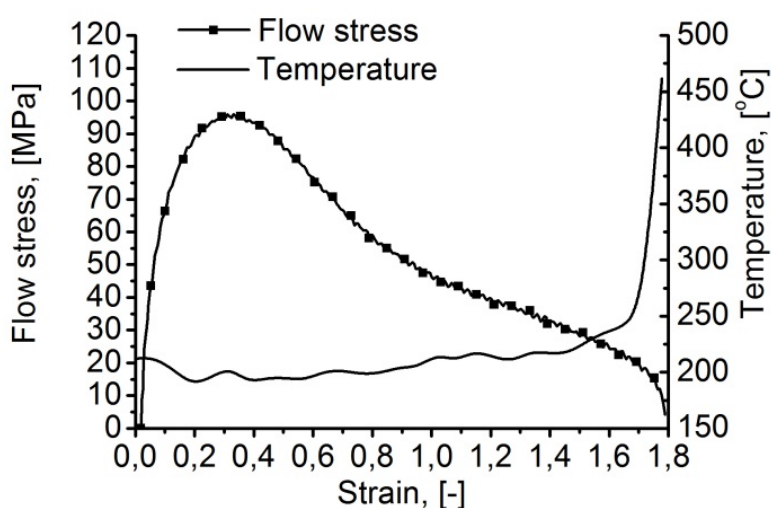

c)

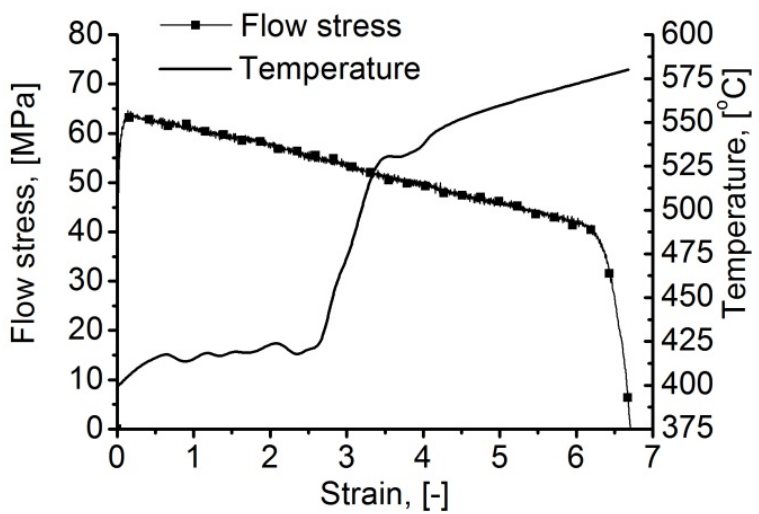

Generating of complex deformation scheme in tested material by conducting the tensile process with torsion (Fig. 6) resulted in decreasing of its plasticity, the value of which was close to the values obtained during the tensile tests (Fig. 4). Analyzing the nature of the course of yield stress (derived from tension and torsion), it was found that they have substantially different waveform than in tensile or constrained torsion tests. Application of a complex deformation scheme also resulted in a slightly different thermal effect of the deformation process. The highest temperature increase of about $250^{\circ} \mathrm{C}$ were recorded for the process carried out at temperature of $300^{\circ} \mathrm{C}$.

b)

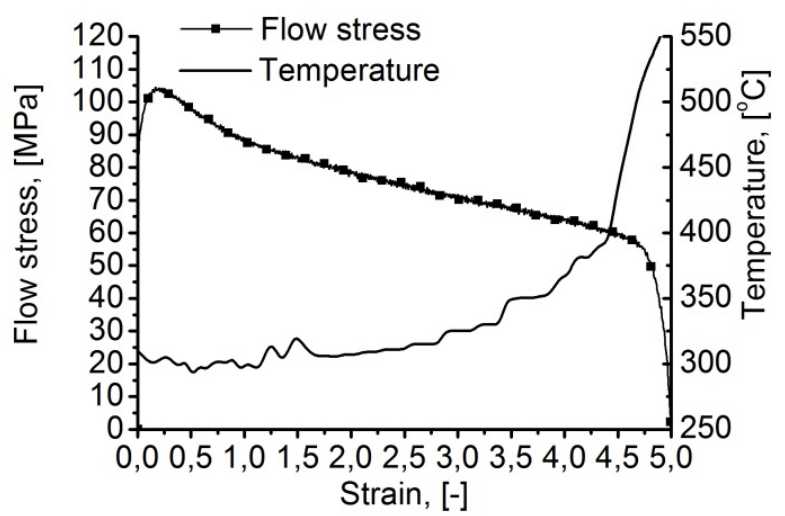

Fig. 5. Stress-strain dependencies received during torsion test with deformation rate $1 \mathrm{~s}^{-1}$ at temperature of: a) $200^{\circ} \mathrm{C} \mathrm{b)} 300^{\circ} \mathrm{C}$ c) $400^{\circ} \mathrm{C}$

The EBSD technique was applied in the next stage of the study to observe the microstructure of deformed materials. In Fig. 7, Fig. 8, Fig. 9 and Fig. 10 has been shown the results of EBSD analysis depicted in the form of maps of the crystallographic orientation of individual grains and maps representing the analysis of the microstructure.

Conducting the torsion test gave as a result a strong grain refinement, as shown in Figures $7 \mathrm{a}$ and $8 \mathrm{a}$. The image resulted in the torsion test at temperature of $200^{\circ} \mathrm{C}$ has shown a heterogeneous distribution of the grain in analyzed section. A quantitative analysis showed that approx. $26 \%$ of the viewing area consisted of grains with size of about 2 micrometers and the participation of the grains sized of 30-40 micrometers was approximately $20 \%$ of the observed surface. And performing the torsion process of 7075 aluminum alloy at temperature of $400^{\circ} \mathrm{C}$ allowed to obtain fine-grained structure with a grain size in the range of 1-8 micrometers. The observed grain distribution is homogeneous (Fig. 8a).

Simultaneously carrying out tensile and torsion have caused non-uniform grain refining in analyzed longitudinal section of the sample (Fig. 9a and 10b). The measured grain size distribution for the material deformed at temperature of $200^{\circ} \mathrm{C}$ was in the range from approx. 5 to approx. 90 micrometers (Fig. 9b), whereas for the samples deformed at temperature of $400^{\circ} \mathrm{C}$ in range from approx. 5 to approx. 100 micrometers (Fig. 10b). Operating at a lower temperature has approx. $50 \%$ of grains with a larger diameter in the analyzed surface of the sample, which confirms a lower plasticity and a high level of yield stress. The temperature increase up to $400^{\circ} \mathrm{C}$ causes a change of share large grains to about $36 \%$, which increase the limiting deformability of the alloy. 
a)

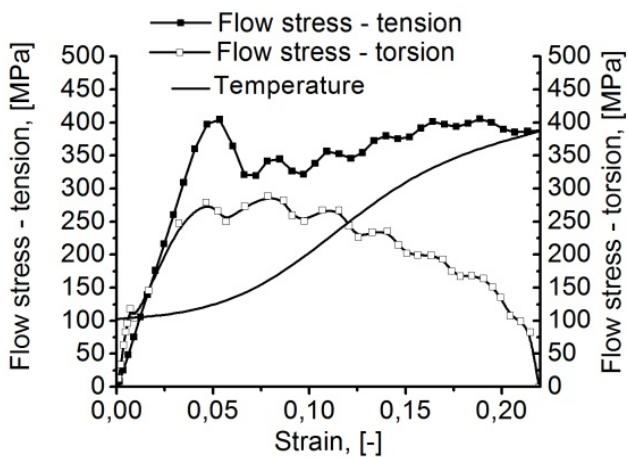

c)

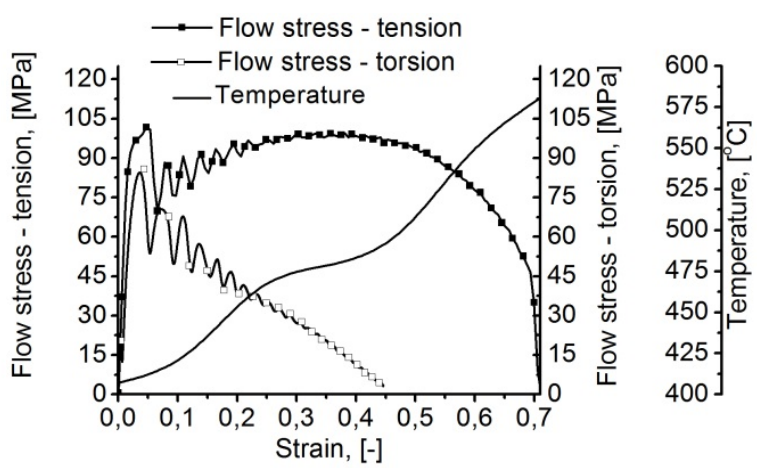

b)

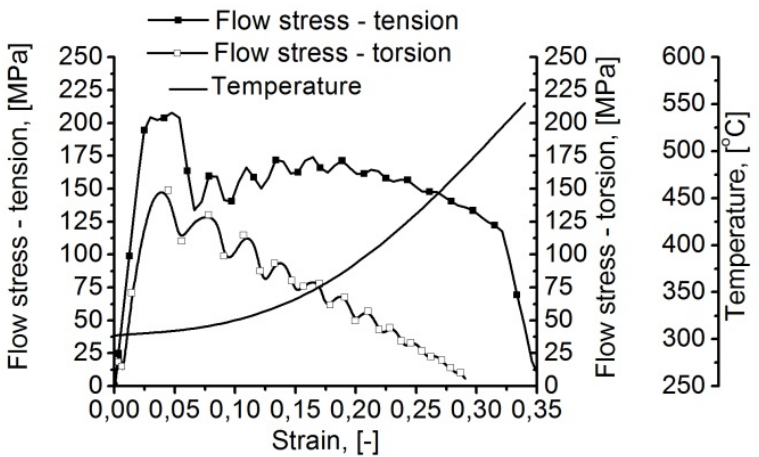

Fig. 6. Stress-strain dependencies received during tensile test with torsion for deformation rate $1 \mathrm{~s}^{-1}$ at temperature of: a) $200^{\circ} \mathrm{Cb}$ ) $300^{\circ} \mathrm{C}$ c) $400^{\circ} \mathrm{C}$

a)

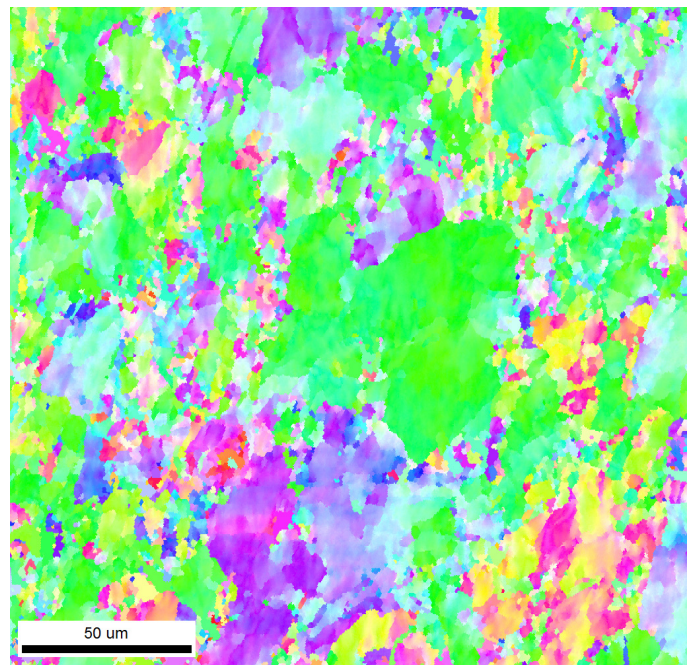

b)

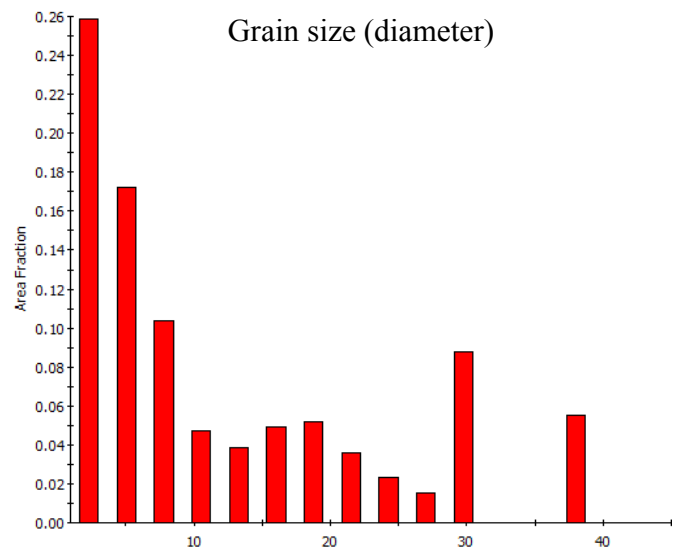

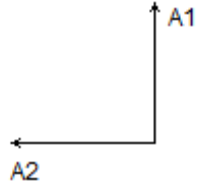

Color Coded Map Type: Inverse Pole Figure [001]

Aluminum_0011176

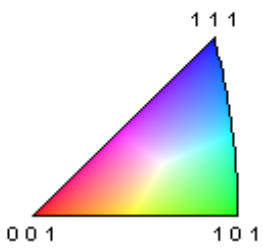

Texture Name: Harmonic: $L=16, \mathrm{HW}=5.0$

Calculation Method: Harmonic Series Expansion Series Rank (I): 16

Gaussian Smoothing: $5.0^{\circ}$

Sample Symmetry: Triclinic

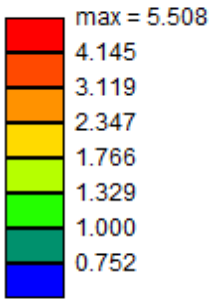

Fig. 7. The results of EBSD analysis of tested aluminum alloy deformed in torsion test at temperature of $200^{\circ} \mathrm{C}$ with strain rate $1 \mathrm{~s}^{-1}$ a) microstructure picture, $b$ ) diagram of grain size distribution 
a)

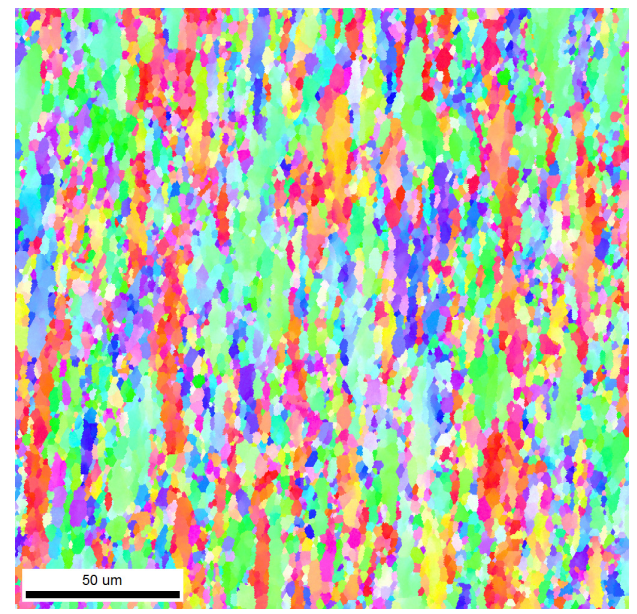

b)

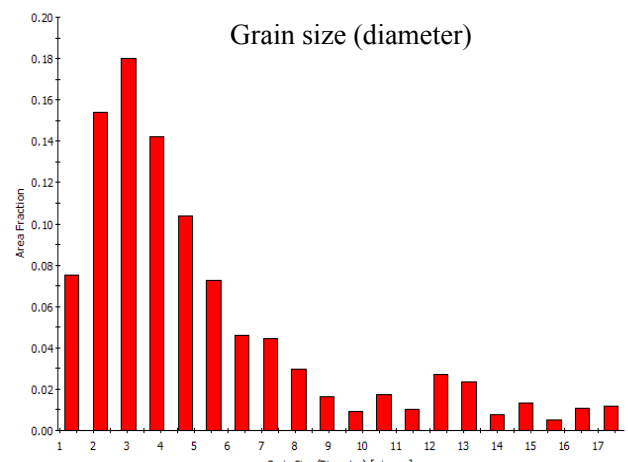

Color Coded Map Type: Inverse Pole Figure [001]

Aluminum_0011176

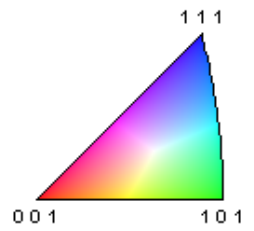

Texture Name: Harmonic: $L=16, \mathrm{HW}=5.0$

Calculation Method: Harmonic Series Expansion

Series Rank (I): 16

Gaussian Smoothing: $5.0^{\circ}$

Sample Symmetry: Triclinic

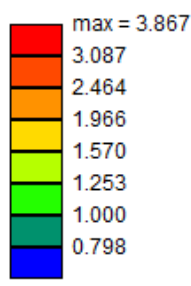

Fig. 8. The results of EBSD analysis of tested aluminum alloy deformed in torsion test at temperature of $400^{\circ} \mathrm{C}$ with strain rate $1 \mathrm{~s}^{-1}$ a) microstructure picture, b) diagram of grain size distribution

a)

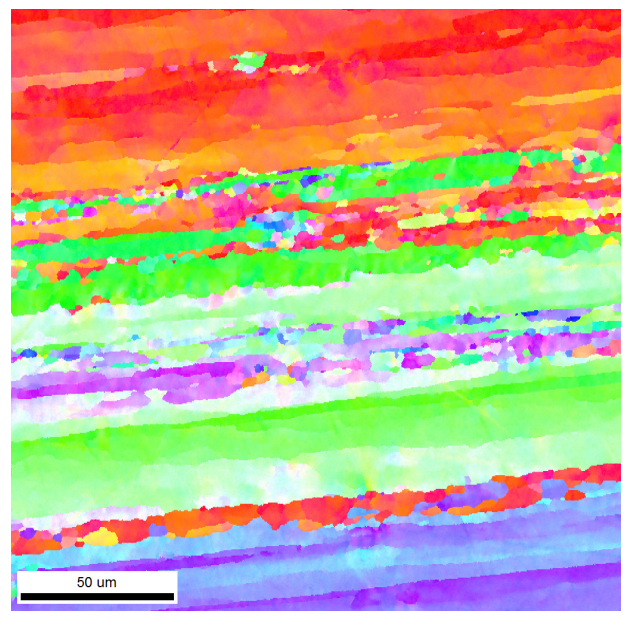

b)

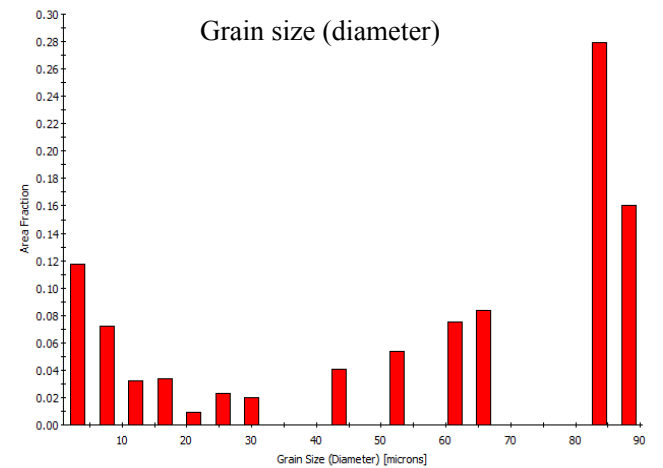

Color Coded Map Type: Inverse Pole Figure [001]

Aluminum_0011176

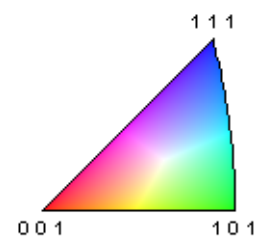

Texture Name: Harmonic: $L=16, H W=5.0$

Calculation Method: Harmonic Series Expansion

Series Rank (I): 16

Gaussian Smoothing: $5.0^{\circ}$

Sample Symmetry: Triclinic

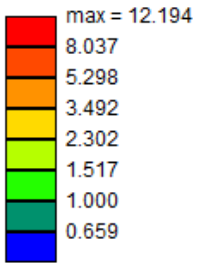

Fig. 9. The results of EBSD analysis of tested aluminum alloy deformed in tensile test at temperature of $200^{\circ} \mathrm{C}$ with strain rate $1 \mathrm{~s}^{-1}$ a) microstructure picture, b) diagram of grain size distribution 
a)

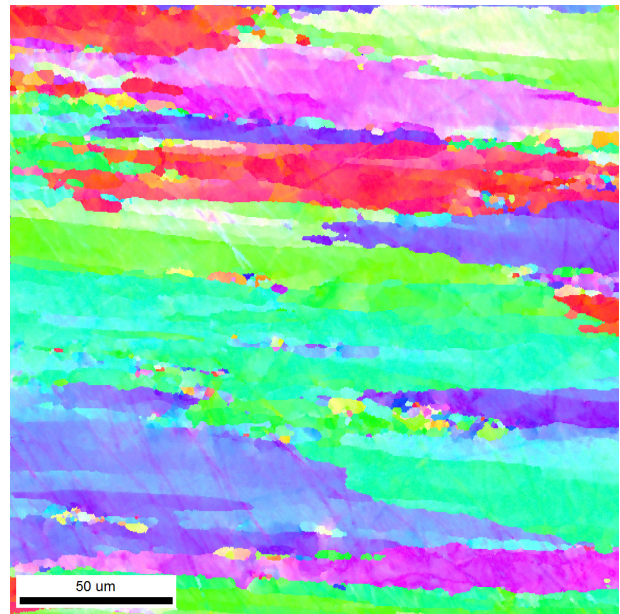

b)

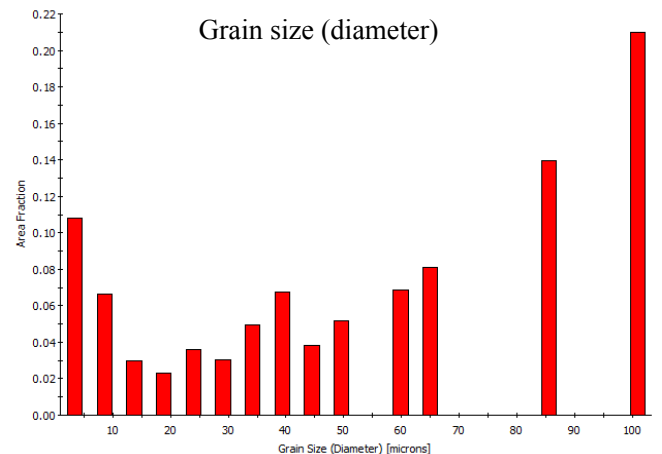

Color Coded Map Type: Inverse Pole Figure [001]

Aluminum_0011176

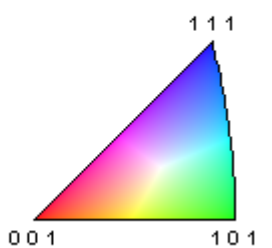

Texture Name: Harmonic: $\mathrm{L}=16, \mathrm{HW}=5.0$

Calculation Method: Harmonic Series Expansion

Series Rank (I): 16

Gaussian Smoothing: $5.0^{\circ}$

Sample Symmetry: Triclinic

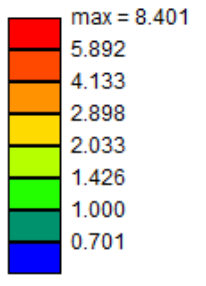

Fig. 10. The results of EBSD analysis of tested aluminum alloy deformed in tensile test at temperature of $400^{\circ} \mathrm{C}$ with strain rate $1 \mathrm{~s}^{-1}$ a) microstructure picture, $b$ ) diagram of grain size distribution

\section{Conclusions}

After making strength testing of 7xxx series aluminum alloys, and after analysis of the results, the following conclusions can be drawn:

- $\quad$ the plastometric tests for $7 \mathrm{xxx}$ series aluminum alloy have shown that, under investigated conditions, there is significant impact of deformation scheme and temperature of the process on the yield stress value of tested material;

- a significant impact of temperature and applied deformation scheme to the analyzed thermal effect during the process of deformation was shown;

- $\quad$ in studied range of deformation parameters the highest limiting deformability showed 7075 aluminum alloy during deformation in torsion test, which was confirmed by the studies of the material structure analysis;

- $\quad$ in studied range of deformation parameters the connection of torsion and tensile process caused decrease of limiting deformability, increase of yield stress level and an increase of measured thermal effect.

\section{REFERENCES}

[1] N. Jin, H. Zhang, Y. Han, W. Wu, J. Chen, Mater. Charact. 60, 530-536 (2009).

[2] Alcoa 7075 data sheet (PDF), accessed October 13 (2006).
[3] Y. Yang, Z. Zhang, X. Li, Q. Wang, Y. Zhang, Mater. Des. 51, 592-597 (2013).

[4] M. R. Rokni, A. Zarei-Hanzaki, A. A. Roostaei, H. R. Abedi, Mater. Des. 32, 2339-2344 (2011).

[5] H. Dyja, A. Gałkin, M. Knapiński, Reologia metali odkształcanych plastycznie, seria: Monografie nr 190, Wyd. P.Cz., Częstochowa, 160-165, 217-220 (2010).

[6] A. Gryc, T. Bajor, H. Dyja, S. Sawicki, K. Laber, Metallurgy 53, 4, 489-492 (2014).

[7] H. Dyja, K. Sobczak, A. Kawałek, M. Knapiński, Metallurgy 52, 1, 35-38 (2014).

[8] A. Kawałek, H. Dyja, J. Markowski, Metallurgy 42, 3, 207-211 (2003).

[9] F. Grosman, E. Hadasik, Technologiczna plastyczność metali. Badania plastometryczne, Wyd. PŚ, Gliwice, 11-12 (2005).

[10] A. M. Galkin, Badania plastometryczne metali i stopów, Politechnika Częstochowska, Seria Monografie nr 15, Wyd. P.Cz., Częstochowa, (1990).

[11] T. Dróżdż, H. Dyja, J. Mrożek, Pomiar i sterowanie plastometrem skrętnym przy zastosowaniu techniki komputerowej. Metrologia i systemy pomiarowe Z 16, 335-342 (1993).

[12] H.W. Kim, S.B. Kang, N. Tsuji, Y. M. Amino, Metallurgical and Materials Transactions A 36, 11, 3151-3163 (2005).

[13] R.Z. Valiev, I.V. Alexandrov, Y.T. Zhu, T.C. Lowe, J. Mater. Res. 17, 5-8 (2002).

[14] P. Szota, S. Mróz, A. Stefanik, R. Mola, Materialwissenschaft und Werkstofftechnik 46, 3, 285-293 (2015). 